\title{
The public health context of violence in Colombia
}

\author{
Richard Garfield ${ }^{1,2}$ and Claudia Patricia Llanten Morales ${ }^{3}$
}

Suggested citation Garfield R, Llanten Morales CP. The public health context of violence in Colombia. Rev Panam Salud Publica. 2004;16(4):266-71.

ABSTRACT Objective. Among the countries of the Americas, Colombia has the highest level of deaths due to homicides and armed conflict. The objective of this research was to combine and contrast information from various sources on deaths due to violence in Colombia in order to identify major trends in violence in the country and to compare those trends with those in other nations of the Americas.

Methods. We drew together information from a wide array of sources, including the Government of Colombia, Colombian forensic institutions, nongovernmental organizations, and international research centers. We considered the impact of the violence on mortality as well as in such areas as nonfatal injuries, displacement of persons, and kidnappings.

Results. While there have been many deaths in Colombia directly related to military conflict, there have been many more deaths and injuries as an indirect result of war. The highest levels of deaths directly related to violence occurred during the 1990-1995 period. Although deaths due directly to armed conflict declined in the late 1990s, the related events of kidnappings and displacement did not.

Conclusions. Efforts to reduce the violence-related suffering in Colombia must consider both direct and indirect causes of mortality as well as nonfatal outcomes such as kidnappings and displacement.

Key words Violence, war, homicide, crime victims, Colombia.

In the 1990s one of the 10 largest conflicts in the world took place in Colombia. Now in the first decade of the 21st century, Colombia is still struggling to deal with the only major

\footnotetext{
1 Columbia University, School of Nursing, New York, New York, United States of America. Send correspondence to: Richard Garfield, Box 6, 630 West 168th Street, New York, New York 10032, United States of America; telephone: 212-305-3248; fax: 212-305-6937; e-mail: rmg3@columbia.edu

2 London School of Hygiene and Tropical Medicine, Health Policy Unit, London, United Kingdom.

3 Universidad del Valle, Cali, Colombia.
}

unresolved military conflict in the Americas, with the Western Hemisphere's highest level of deaths due to either homicide or armed conflict (1). Sources of data on deaths in conflicts have generally been biased and unreliable (2). Colombia is one of about a dozen countries in the world with long-standing conflicts not resolved after the end of the cold war (3). At the beginning of the 21st century, Colombia was the only nation in the Americas that continued to experience high levels of conflict. During most years since the end of World War II, some kind of organized armed conflict has occurred in the country.

For this article, violence is defined as the intentional use of force to cause harm. Violence was the cause of death of about $5 \%$ of the world's population in the 20 th century, but less than $1 \%$ of the population in the years since the end of the World War II (4). Violence is one of the leading causes of disabilityadjusted life years in nearly all coun- 
tries in the Americas (5). While the rates of mortality from many causes have declined in the last decade, deaths due to injuries have increased. Nowhere in the Americas is the proportion of deaths due to violence greater than in Colombia.

Following World War II, a civil war from 1948 to 1956 caused an estimated 200000 deaths in Colombia (6). From the end of that civil war until the beginning of leftist insurgency in the mid-1960s no large-scale organized political violence occurred. Homicide mortality during this period is thus considered a baseline rate. The insurgencies in the 1960s developed as a social movement closely linked to international political events. Antigovernment rebels during the 1970s established relations with Colombia's emerging illicit drug cartels. By the 1980s collective violence in Colombia was increasingly a product of national rather than international dynamics. Hostage-taking and a massacre in the country's Supreme Court in 1985 were followed by a tentative move toward integration into legal political activities during the 1988-1991 period, similar to trends with insurgencies in other parts of Latin America. However, this change in Colombia was cut short due to the killing of leaders in this movement. When the cold war ended, leftist insurgents and rightist armed groups became more entrepreneurial, generating funds via drug sales, protection of illicit drug production, and hostagetaking. This change was reflected in rising homicide rates, especially during 1987 to 1995. Military confrontations declined somewhat during the latter 1990s, during an extended period of negotiations between rebels and the Government. Large territorial concessions to the insurgents during this period of negotiations were partly responsible for a rise in the number of internally displaced people. When these negotiations ended in 2002 the war between leftist insurgents and right-wing death squads and the Government again intensified.

\section{MATERIALS AND METHODS}

In this study we draw together information from a wide array of sources to characterize the public health impact and consequences of violence in Colombia. We compare Colombia's experience to that of other countries in the Americas. We examine documentation on the impact of violence be- yond measures of mortality. This case study can contribute to a fuller characterization of the violence and thus help to strengthen public health analysis and to develop interventions.

\section{RESULTS}

\section{Deaths}

A total of 56113 people were registered as dying from external causes in Colombia in 2001 (7). This represents a mortality rate of 149 per 100000 population, which is more than a third of the 420 deaths from all causes per 100000 population. Death from external causes was the second most common cause of death, after all circulatory diseases (176 per 100 000) and ahead of all tumors (81 per 100 000) (8). A reported 27113 deaths, or about half of all externally caused deaths, were reported as homicides (7).

The homicide rate rose from 15 per 100000 residents in 1938 to 55 per 100000 during the bloody civil wars of the 1950s (9). The rate was lower in the 1970s and rose rapidly after 1983 (Figure 1). The rate of homicides peaked in 1991 and then gradually declined. Nevertheless, rates in the late 1990s

FIGURE 1. Homicide rate in Colombia, year, 1958-2003

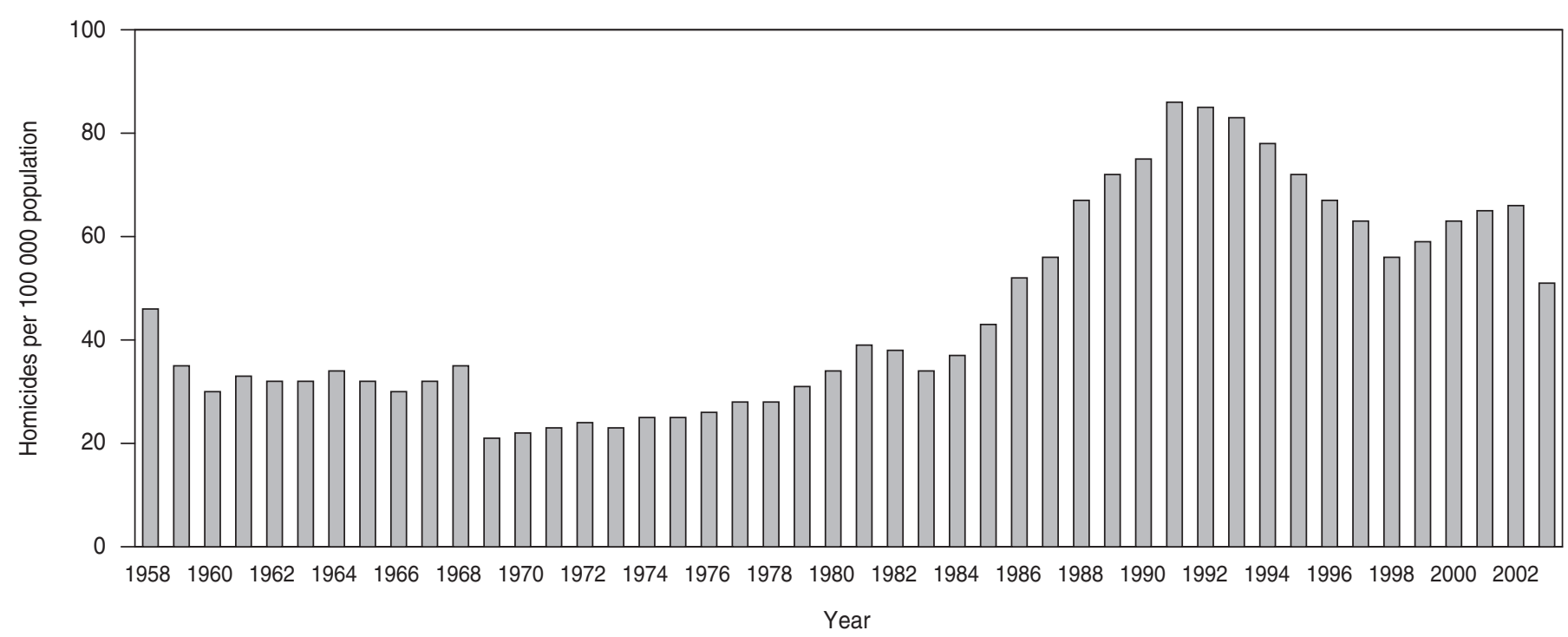

Source: References: 8-11. 
were still higher than at any time prior to 1988 .

There were half a million homicides during the 1980-2003 period, including an estimated 32000 conflictrelated deaths. Deaths that were the direct result of war represented a yearly rate varying from $8 \%$ to $14 \%$ of all reported externally caused deaths (8-13). These were deaths occurring in armed confrontations among identified combatant groups. Most of the other homicide deaths were recorded as resulting from personal vendettas, vigilantism, or vengeance attacks. Many of these were likely also the indirect result of war (e.g., vengeance for deaths of family members directly caused by war), easy access to firearms, competition in the illicit drug trade, and impunity from law enforcement.

In recent decades, violent deaths of all kinds in Colombia have been much more common among men than among women (8-13). Men have been on average about 10 times as likely to die in a homicide, 4 times as likely to die due to unintentional injuries, and 3 times as likely to die due to suicide. The majority of deaths due to each of those causes has occurred among persons 15 to 34 years old.

Independent from Colombia's national death registration system, a variety of estimates and guesses have been made about the number of people killed in military conflict. Many of the sources provide estimates for arbitrary multiyear periods. Sources for these estimates include press reports, human rights reports, educated guesses, and hearsay. Given the different approaches that they apply, these estimates are not directly comparable, though they reflect similar trends in the direction and magnitude of mortality over time (Table 1 ).

Apart from these sources (Table 1), the Correlates of War project made qualitative estimates of relative magnitude, identifying the years 1987 to 1995 as those of highest mortality intensity (22). With the exception of the highest total estimate of deaths in Table 1, which is from Amnesty International, there is general agreement about trends of total war-related deaths. The

TABLE 1. Estimates of total war-related deaths, Colombia, 1963-2002

\begin{tabular}{|c|c|c|c|}
\hline Source of estimate & Years covered & $\begin{array}{l}\text { Estimated } \\
\text { deaths }\end{array}$ & $\begin{array}{l}\text { Average annual } \\
\text { estimated deaths }\end{array}$ \\
\hline \multicolumn{4}{|l|}{ International Institute for Strategic } \\
\hline Studies (14) & $1963-2000$ & 47000 & 1270 \\
\hline \multicolumn{4}{|l|}{ Interdisciplinary Research Programme on } \\
\hline $\begin{array}{l}\text { Root Causes of Human Rights Viol } \\
\text { (15) }\end{array}$ & 1964-1999 & 37000 & 1057 \\
\hline \multicolumn{4}{|l|}{ Stockholm International Peace Research } \\
\hline Institute (16) & 1969-1999 & 35000 & 1167 \\
\hline Center for Systemic Peace (17) & 1984-1999+ & 50000 & 3333 \\
\hline Amnesty International (18) & 1985-2002 & 60000 & 3529 \\
\hline Sivard (19) & $1986-1995$ & 45000 & 5000 \\
\hline Human Rights Watch (20) & $1988-1998$ & 30000 & 3000 \\
\hline International Rescue Committee (21) & 1990-2002 & 45000 & 3750 \\
\hline
\end{tabular}

Stockholm International Peace Research Institute (SIPRI), which does extensive monitoring of government documents, military analyses, and press reports to develop mortality estimates, provides single-year estimates, but only for years when there are estimated to be more than 1000 war deaths.

By combining the SIPRI annual estimates and the other sources in Table 1, we have produced a synthetic set of annual estimates (Figure 2). There is a general trend of rising mortality in the early 1990s, followed by a partial decline. In most years the number of estimated war dead is about $10 \%$ of all homicides. This level is similar to the percentage calculated by the country's forensic reporting system, of 10\%-13\% per year (13). The estimated number of war deaths thus appears to provide a valid indicator of a general trend but an imprecise estimator of the exact number of deaths directly attributable to the war.

\section{Context of deaths}

In most years of the 1990 s about $85 \%$ of the homicides were committed with guns. More than half occurred in public places. About a third of all homicides were registered as due not to war but as personal vendettas or "payback" for previous acts. Many of these deaths were likely provoked in re- sponse to war-related killings or the environment of impunity fostered by war. How many of the other deaths occurred as an indirect result of the war? Murray et al. (5) have defined indirect war deaths as all those that have occurred in excess of the number that would have occurred if there were no war. To operationalize this definition, one would have to know more information than is available about the circumstances of those who died outside of the context of battle.

The $10 \%-13 \%$ of homicides that result from armed conflict already account fully for the estimated 3700 war dead per year in the 1990s. If a third of the "payback" deaths are war-related, then armed conflict was responsible for about 8000 deaths per year in the 1990s. About $11 \%$ of all deaths go unreported, and $13 \%$ are estimated to be poorly recorded. This represents about $25 \%$ more deaths than were registered. If poorly recorded deaths have the same proportion of war-related deaths as do well-recorded deaths, an estimated total of about 10000 deaths per year occurred as the direct or indirect result of war.

\section{Comparisons with other countries}

The rate of reported homicides in Colombia is very high compared with other nations. In 1995 the rate in Colombia (60.8 per 100 000) was seven 
FIGURE 2. Total homicides and war deaths in Colombia, 1980-1999

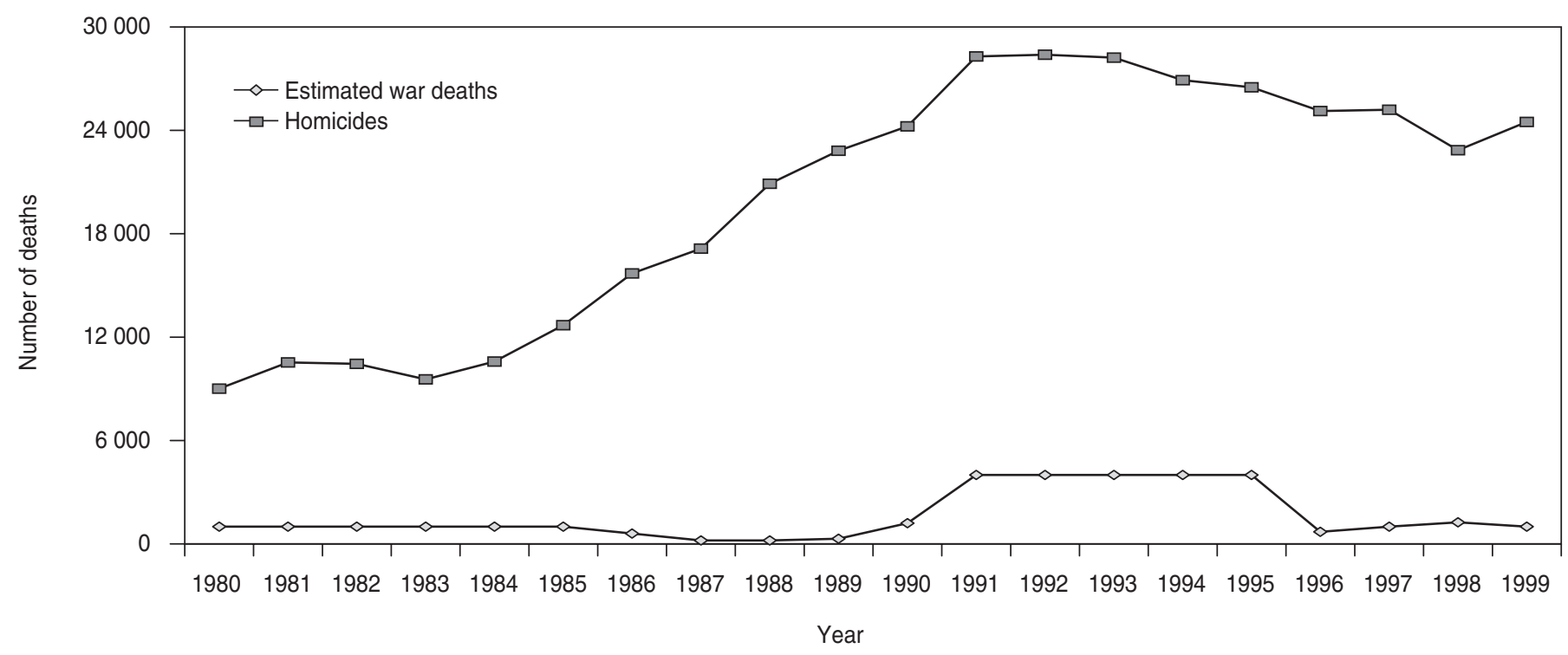

Sources: Table 1 and References 7-13.

times as high as in the United States (8.3 per 100 000) and more than 30 times as high as in Canada (1.8 per 100 000) (23). In Colombia there are about 3 times as many homicides as motor-vehicle-related deaths. In all the other countries in the Americas with data, the ratio is reversed, with at least twice as many vehicular deaths as homicide deaths. In the 1990s, homicides constituted the first or second most common cause of death for all age groups in Colombia except among those $0-4$ years old.

If an estimate of 40000 total direct war-related deaths is used for the 1985-2001 period, the percentage of all Colombians who were killed by the war over that period would be $0.1 \%$. This is lower than the $1 \%-4 \%$ killed in the Central American wars in the 1980s. ${ }^{4}$ Nevertheless, Colombia's large population (about 40 million people in 2000) and the long duration of the war make the conflict's impact greater than the relatively lower death rates alone would suggest.

\footnotetext{
4 Garfield R, Drucker E. Counting the dead: epidemiologic analysis of civil conflict, warfare, and genocide [unpublished].
}

\section{Nonfatal outcomes}

Many nonfatal expressions of violence, including injuries, go unreported in Colombia. This is especially likely to be true for conflict-related wounds, since military or paramilitary groups can use this information against the injured person. Only $1 \%$ of reported wounds were registered as resulting from armed conflict. Since the majority of serious injuries are treated in hospitals, it is assumed that a stable level of underreporting exists. Nonetheless, reporting is influenced by shifts in case definition and active surveillance. With the establishment of the National Institute for Legal Medicine and Forensic Sciences, reporting of serious injuries increased by $15 \%$, from 527 per 100000 in 1994 to 608 per 100000 in 1995 (7).

Of the total 163230 registered nonfatal injuries reported in 1995, 76.5\% were reported as intentional in nature. These 124871 injuries represent 2.2 for each reported death due to external causes. By comparison, there are financial incentives for reporting traffic injuries, such as being reimbursed from health and car insurance. There were seven nonfatal traffic injuries reported for each traffic-related death. Two-thirds of all registered injuries were caused by firearms.

\section{Displacement}

Armed conflict has occurred in 1000 of the country's 1097 municipalities. This has produced a very high level of displacement of people within the country as well as emigration to other countries. There are currently estimated to be 1.1 to 1.5 million displaced persons in total in the country, representing about 300000 families. About $6 \%$ of the country's people have been displaced at some time. Most of them moved from rural villages to periurban slums, with a resulting decline in both their economic productivity and quality of life. Among those who were displaced, $55 \%$ of them were under age 18, about three-fourths reported lacking health services (24), and $40 \%$ of the displaced children reported not regularly attending school. Many have settled or resettled over the years and may no longer be considered displaced (25). 
FIGURE 3. Violent events, Colombia, 1964-2003

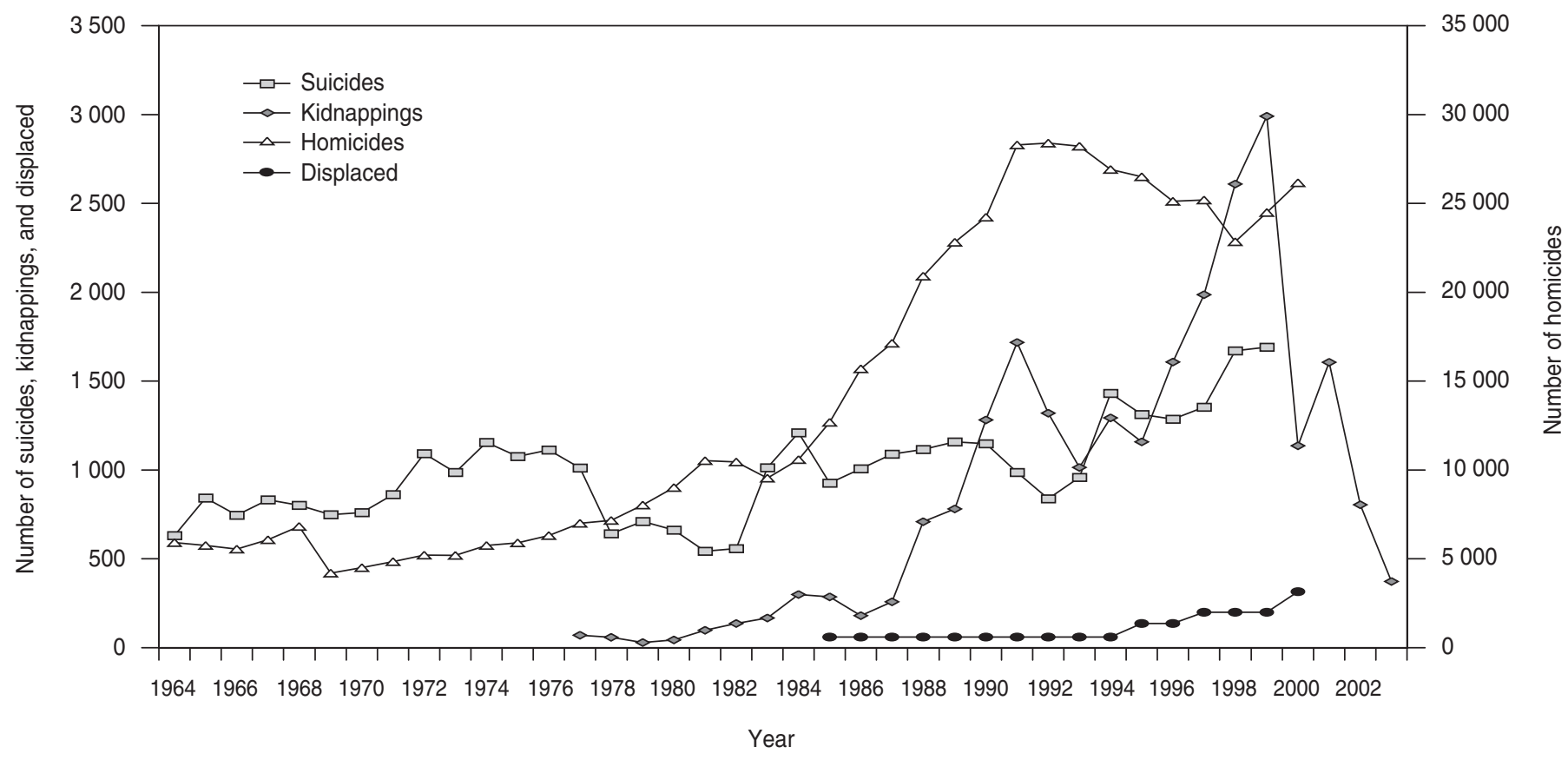

Sources: References: 7-13

\section{Kidnappings and other indirect effects}

In most years Colombia leads the world in the number of kidnappings. While the number of homicides and of directly war-related deaths declined in Colombia in the latter half of the 1990s, the epidemic of kidnappings and displacement that the war generated continued to rise (Figure 3). Suicide rates also rose. The social and economic costs of the conflict have greatly slowed development. Many communities have been marginalized, much of the potentially productive population is bearing arms, and the provision of basic services in many areas has been interrupted.

\section{DISCUSSION}

We used several nontraditional data sources to identify trends in mortality and nonfatal impacts over time. These sources, including reported deaths among police and reports from human rights organizations, provided an added dimension in characterizing violence in Colombia. Despite limitations in the use of official sources to capture "lesions caused by war," existing sources proved to be relatively good for tracking deaths resulting directly from armed conflict. The political violence that causes deaths within a country is informal and interpersonal, so it is far more difficult to enumerate deaths that are an indirect result of that conflict than it is to count the number directly linked to the fighting. In Colombia it appears that the number of indirect deaths is much higher than the number of deaths directly due to the conflict.

The organizations whose data are summarized in Table 1 do not do their own original and comprehensive collection of data on deaths. Their estimates of total deaths vary by a factor of two, and the average number of estimated deaths per year varies almost five-fold among these sources. These summaries are made through an unsystematic collection of estimates and guesses. Systematic histories and the elaboration of standard definitions are needed to better determine the validity of the sources used and the estimation methods.

Such an effort would likely provide important information to assist in the identification of potential interventions to reduce violent deaths. The causes and correlates of violence in Colombia have changed several times over the last four decades. While the number of deaths resulting directly from the conflict has declined, some of the other events stimulated by the conflict have grown to all-time highs. It appears that displacement and kidnappings have taken on a new character and will need to be dealt with apart from efforts to reduce mortality.

Acknowledgments. The authors gratefully acknowledge the assistance of Ennio Cufino of UNICEF; Juan Velásquez of the Instituto de Medicina Legal, Cali; and Victoria Espitia, CISALVA Institute, Universidad del Valle, Cali. 


\section{REFERENCES}

1. Sollenberg M, Wallensteen P. Patterns of major armed conflicts, 1990-2000. Available from: http://projects.sipri.se/conflictstudy/ 2001MACapp1a.pdf [Internet site]. Accessed 7 July 2004.

2. White M. Source list and detailed death tolls for the man-made megadeaths of the twentieth century. Available from: http://users. erols.com/mwhite28/warstats.htm [Internet site]. Accessed 7 July 2004.

3. World Health Organization. World report on violence and health. Geneva: WHO; 2002.

4. Garfield RM, Nuegut A. Epidemiologic analysis of warfare: a historical review. JAMA. 1991;266(5):688-92.

5. Murray CJL, King G, Lopez AD, Tomijima N, Krug EG. Armed conflict as a public health problem. BMJ. 2002;324:346-9.

6. LeoGrande WM, Sharpe KE. Two wars or one? Drugs, guerrillas, and Colombia's new violencia. World Policy J. 2000;17(30):1-11.

7. Instituto Nacional de Medicina Legal y Ciencias. Forenses: datos para la vida. Santa Fe de Bogotá: Instituto Nacional de Medicina Legal y Ciencias; 2001.

8. Gobierno de Colombia. Situación de salud de Colombia: indicadores básicos 2002. Santa Fe de Bogotá: Ministerio de Salud; 2003.

9. Colombia, Policía Nacional. Criminalidad. Santa Fe de Bogotá: Policía Nacional; 2000.

10. Colombia, Ministerio de Defensa Nacional. Homicidio y control de armas en Colombia.
Santa Fe de Bogotá: Ministerio de Defensa Nacional; 2001.

11. Gobierno de Colombia. Informe DDHH Mindefensa y Vicepresidencia de la República, 2001. Santa Fe de Bogotá: Gobierno de Colombia; 2002.

12. Gobierno de Colombia. Informe DDHH Mindefensa y Vicepresidencia de la República, 2002. Santa Fe de Bogotá: Gobierno de Colombia; 2003.

13. Instituto Nacional de Medicina Legal y Ciencias. Forenses: datos para la vida. Santa Fe de Bogotá: Instituto Nacional de Medicina Legal y Ciencias; 2000.

14. International Institute for Strategic Studies. [Internet site]. Available from: http://www. iiss.org/conferencepage.php?table=confMain \&itemID $=61 \&$ returnTo=conferencepage.php \&confID=61. Accessed 8 March 2003.

15. Jongman, AJ. World conflict and human rights map, 2001-2002. Leiden: PIOOM; 2003.

16. Stockholm International Peace Research Institute. World armaments and disarmament: SIPRI yearbook. Stockholm: SIPRI; 2000.

17. Marshall MG. Major episodes of political violence 1946-2002 [Internet page]. Available from: http://members.aol.com/CSPmgm/ cspframe.htm. Accessed 25 March 2003.

18. Amnesty International. Annual report on Colombia 2002. Available from: http://web. amnesty.org/web/ar2002.nsf/amr/colombia! Open [Internet site]. Accessed 8 July 82004.
19. Sivard RL. World military and social expenditures 1991. Washington, D.C.: World Priorities; 1996.

20. Human Rights Watch. World report 2002. Colombia. Available from: http://www.hrw. org/wr2k2/americas4.html [Internet site]. Accessed 8 July 2004.

21. White M. Mid-range wars and atrocities of the twentieth century. Available from: http:// users.erols.com/mwhite28/warstat4.htm\#Col [Internet site]. Accessed 8 July 2004.

22. Small M, Singer JD. Resort to arms: international and civil wars, 1816-1980. Beverly Hills: Sage; 1982.

23. Pan American Health Organization. Health in the Americas, 2002 edition. Washington, D.C.: PAHO; 2002.

24. U.S. Committee for Refugees. Principal sources of internally displaced people [Internet page]. Available from: http://www. refugees.org/downloads/wrs03/SStable6.pdf. Accessed 14 September 2004.

25. Consultoría para el Desplazamiento Forzado y los Derechos Humanos. Un país que huye. Santa Fe de Bogotá: Consultoría para el Desplazamiento Forzado y los Derechos Humanos; 1999

Manuscript received 25 April 2003. Revised version accepted for publication on 28 July 2004.

RESUMEN Objetivo. De los distintos países del continente americano, Colombia tiene el más alto porcentaje de muertes por homicidios y conflictos armados. El objetivo de esta investigación ha sido combinar y contrastar información obtenida de diferentes fuentes sobre la violencia en Colombia con el fin de identificar las principales tendencias que muestra la violencia en el país y comparar dichas tendencias con las observadas en otros países del continente.

Métodos. Recogimos información de una gran variedad de fuentes, entre ellas el Gobierno de Colombia, institutos forenses colombianos, organizaciones no gubernamentales y centros de investigación internacionales. Examinamos el impacto de la violencia sobre la mortalidad y las heridas no mortales, el desplazamiento humano y los secuestros.

Resultados. En Colombia muchas muertes han sido consecuencia directa del conflicto armado; no obstante, muchas otras muertes y lesiones son el resultado directo del estado de guerra. El mayor porcentaje de muertes directamente asociadas con la violencia tuvo lugar en el período de 1990-1995. Aunque las muertes directamente atribuibles al conflicto armado se redujeron en las postrimerías de los años noventa, los secuestros y el desplazamiento humano que con ellas se asocian no disminuyeron. Conclusiones. A la hora de idear estrategias para reducir el sufrimiento ocasionado por la violencia en Colombia, es aconsejable tener en cuenta las causas directas e indirectas de la mortalidad y también otros siniestros que no son mortales, tales como los secuestros y el desplazamiento de seres humanos. 